\title{
THE RISK OF PLACING PRODUCTS FROM NEW MATERIALS ON THE MARKET
}

\author{
Šárka VILAMOVÁ, Roman KOZEL, Karel BAŘINKA, Drahomír FOLTAN, Jakub CHLOPECKÝ \\ VSB - Technical University of Ostrava, Ostrava, Czech Republic, EU \\ sarka.vilamova@vsb.cz, roman.kozel@vsb.cz, karel.barinka.st@vsb.cz, drahomir.foltan.st@vsb.cz,
} jakub.chlopecky@vsb.cz

https://doi.org/10.37904/metal.2019.784

\begin{abstract}
The article deals with possibilities of introducing innovations using new composite materials in the production and sale of precision rifle's barrels. While other parts of weapons have undergone a number of design changes in the past, the barrel has not been altered. Among the main reasons for not changing it are the technical risks and limitations. Other risks when implementing changes are the rather conservative approach of customers towards innovations and the amount of legislative regulations that cause these products to have a long innovation cycle. The aim of the article is to find out the main factors influencing the future marketability of precision rifles using new composite materials in combination with steel when producing barrels. The solution lies in summarizing the complex thermo-mechanical processes that occur in steel barrels during the shot and selecting those attributes that have the greatest potential for commercial use of new composite materials. The outcome of the research efforts of the authors consist in describing the decision-making process for production and commercialization of high-quality precision rifles with new types of barrels with steel core and composite coating that should significantly minimize the existing risks of introducing innovations.
\end{abstract}

Keywords: Composite materials, risks, composite barrel, composite precision rifle, steel, customers, marketing

\section{INTRODUCTION}

Unlike other weapon parts the barrel has not been altered in either its structure or the use of new materials. Yet innovation, whether concerning the steel [1] or other materials [2], is one of the most important ways of increasing the value of a product or keeping it at the level expected by a customer. The authors of this paper try to find out the risks and barriers associated with introducing innovations in precision rifles, weapons that can hit targets even at very long distances. At the same time, the research results of the authors and their colleagues are presented in the preparation of technical and marketing innovations aiming to achieve higher customer satisfaction.

\section{NEW MATERIALS}

Over the past hundred years, there have not been many alterations in the production of precision rifles. From the barrel construction point of view, there have been some development and modernization in the past decade, but the somewhat conservative approach of customers together with the complex interplay of events, which are mostly hidden to the eye and most of the technology, prevent the modernization. High pressures, temperatures, and events at each shot create such complex processes when interacting with each other, that their effect on the material of the barrel is so great changing the conditions of the next shot. On the contrary, the requirement of the shooter is, above all, maintain unchanged conditions so that the weapon behaves the same for every other shot.

Finding new materials that would surpass existing barrel steel was not and is not easy. One common path the research teams around the globe take is the use of composite materials. These materials are composed of two or more substances with different properties, which, together, give the resulting product new properties 
that none of its other components, have. All that results in a positive economic impact, as consequently there is a lower number of components and production procedures. [3]. Due to the positive properties of composites, these materials are used in a wide range of industrial applications [4] and a special testing equipment have been made for them [5]. The arms industry often uses composites that are carbon-bound in the cases of military vehicles [6], firearms [7], ammunition [8] or in a defence system against missiles [9]. One of the modern and potentially interesting ways of innovating the precision rifle's barrels is the layered carbon fibre wrapped to a steel core. Consequent layering and assembling with polymers thus create a very strong and durable composite material with attributes that in many cases exceed the steel barrel, which can be partly replaced. [10].

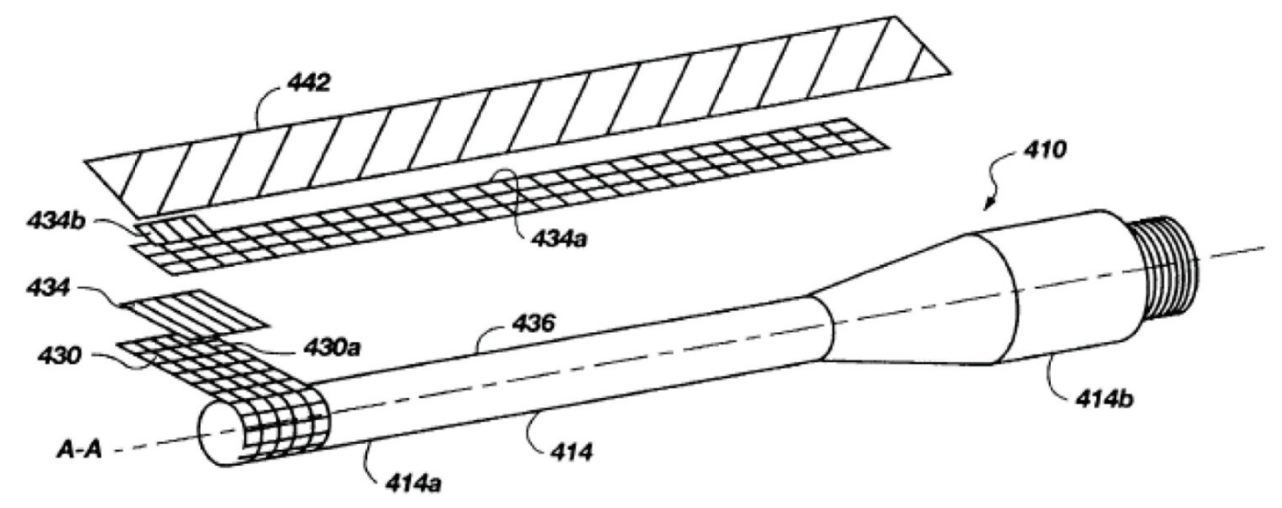

Figure 1 Wrapping carbon fibres on a steel core barrel [10]

The composite provides above all:

- $\quad$ high strength,

- light weight,

- resistance to thermal expansion, and

- $\quad$ high shock absorption capability.

The problem of composite materials can be their wear (e.g., cracks or tears) [11]. And that is why the steel core made, for instance, from stainless steel 416R or barrel steel 15142 still have attributes that the composite cannot have - durability in terms of wear, machinability to required internal bore parameters and shape stability. In the recent years, several producers, focusing mainly on production of commercial weapons, have started to place a composite coating of a barrel on the market. We could name the AR-15 assault rifles or Accuracy sniper rifles as an example. To name a few, Proof research, Carbon six, Christensen Arms and BSF barrels are involved in the production of the composite coating. Many other companies invest in the development in order to follow the new trend and keep their market positions in the case that the suitability of the new material for barrel construction and production proofs successful and becomes massively distributed. But for now, it has been mostly innovators who purchased the composite barrels. Most established arms manufacturers have to wonder how to grasp the new trend and prepare their own product to cover as much market space as possible. History has proven many times that the technical features themselves, albeit the best are not sufficient element for winning the market.

\section{RESEARCH METHODOLOGY AND MAIN OUTCOMES}

The authors of this paper, based on previous experiences [12,13], in collaboration with experts from Česká zbrojovka faced a difficult task. They had to find out which attributes the precision rifles should have for different sorts of customers and how to, in fact, reach them. Hence, the team's research efforts were divided into two areas of research, which are described below. 


\subsection{Customer research}

First, research was conducted among representatives of selected target groups of precision rifles. Specifically, these were interviews with representatives of the armed forces (police and army snipers), athletes (sport shooters) and hobby users (hunters). Each group was represented by at least 30 respondents. The total number of participants in the individual interviews was 134 .

Though the definition of a precision rifle task is simple $=$ to hit a target, a number of research questions have ben raised for researchers to address this issue from multiple points of view. Is it necessary to hit the target with the first shot or is there a room for preparation? Is it sufficient to intervene once or intervene repeatedly in a short time? Is it necessary to hit the target in optimal conditions or can the conditions for each shot differ significantly? In response to these research questions, it is possible to design a specific weapon. Because it is virtually impossible to prepare one weapon to meet all the conditions together, the researchers have focused on identifying differences in the requirements of individual target groups. Table 1 shows the conclusions the author team came to after their research efforts. Differences in individual groups of potential users are generalized, as each profession brings many special situations that can significantly vary from the given answer.

Table 1 Differences in the requirements of individual target groups [own processing]

\begin{tabular}{|c|c|c|c|c|c|}
\hline Requirement & Required weapon property & Policeman & Soldier & $\begin{array}{c}\text { Sport } \\
\text { shooter }\end{array}$ & Hunter \\
\hline First time hit (cold) & A cold shot & Yes & Yes & Rather not & Yes \\
\hline $\begin{array}{c}\text { Repeated hits without } \\
\text { shifting of the shot }\end{array}$ & $\begin{array}{c}\text { Minimal heat impact on the barrel } \\
\text { during the shot }\end{array}$ & Rather not & Yes & Yes & Rather not \\
\hline Weight & $\begin{array}{c}\text { As low as possible while retaining } \\
\text { all the features of the weapon }\end{array}$ & Rather not & Yes & Rather not & Yes \\
\hline Repeated reliability & $\begin{array}{c}\text { Repeated precise shot without } \\
\text { shifting of the shooting point }\end{array}$ & Yes & Yes & Yes & Yes \\
\hline
\end{tabular}

\subsection{Material testing}

The next step in the research process was to verify whether the real outcomes of the customer research could be applied in practice. So the research team engaged in finding out how the barrel should look in case of both: serial and tailor-made productions. As mentioned above, the shot is a set of events that considerably affect the material of the barrel. For simplification, we will not be looking into interactions between the barrel and other components of the weapon or the interaction with the environment. Practically everything has an impact on shooting accuracy. The friction effects $[14,15]$, choice of material, barrel construction, number of grooves in the bore surface, their shape and pitch, the shape of the chamber and the muzzle or tuning of the oscillation so that the muzzle is preferably in the knot. Furthermore, it is necessary to take into account that the conditions of machining are not always ideal. And least but not last, one has to consider the internal stresses in the material, which often occur only after being heated by several shots.

During their research efforts, the research team concluded that it is impossible to calculate all the interactions of all these influences, because not everything can be accurately measured, if at all. And even with all the technology at hand, we will not get outputs without entering the inputs. The authors believe in gradual implementation of such extensive changes, as the replacement of a part of a material mass is, and thus they have chosen the following procedure for composite coating:

1) Testing of a barrel in the original whole-steel form.

2) Barrel modification to a barrel with composite coating.

3) New testing with composite coating. 
4) Comparison and recommendation of the next steps.

This procedure may be followed when preparing the basic concepts for serial weapon production or when producing barrels for specific types of guns. To meet the individual requirements of the customers such procedure is quite unreal, not only due to being timely, but also costly. And so the authors of the article, in collaboration with experts from Česká zbrojovka, kept looking for ways to satisfy the target customers with their individual requirements. They came to the conclusion that one of the means is to calculate the properties of the barrel in advance and follow this calculation when producing the barrel. And with the help of researchers from Česká zbrojovka they have successfully verified it $[16,17]$. Consequent comparison of finite element computation and experimental validation of this calculation showed a match, which proves to be interesting and important for the future development and preparation of marketing communication.

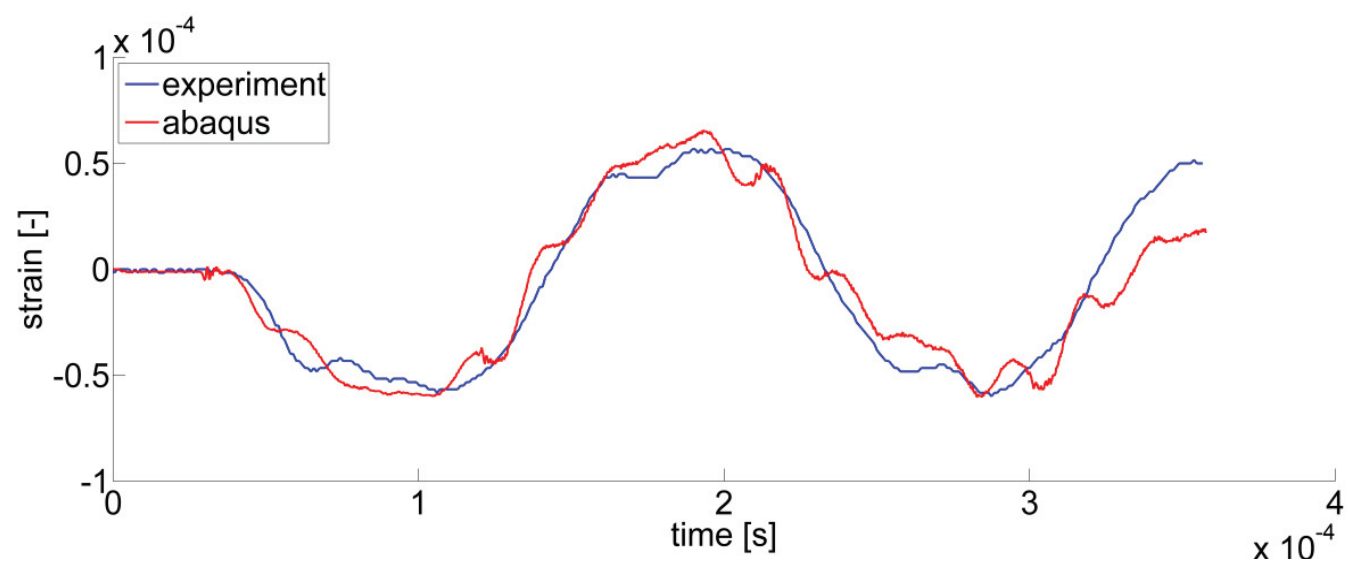

Figure 2 Comparison of time distribution of stress obtained from finite element computation and experimental validation for one selected composite material $[16,17]$

\section{DISCUSSION}

Most people are unfamiliar with testing accurate rifles for long range shooting. An ordinary person usually does not test such a weapon at a shooting range with the possibility of targets far beyond $500 \mathrm{~m}$. In spite of all these limitations and restrictions, even in this area the generally known market rules can be applied. And so only a customer, who is willing to pay for it, appreciates the worth of the product. Entering new markets is described in Master Sun's Art of War mostly in the chapters about great victories and the sources for self-empowerment and self-knowledge. At present, it can be interpreted as follows [18]:

1) Clarifying the opportunity and the ability to compete in a given segment.

2) Being able to take advantage of its own size or the flexibility of a smaller subject.

3) Using a common goal to unite superiors and subordinates.

4) Preparing for the competition and finding the area where the opponent is not prepared.

5) Ensuring good and efficient leadership and preventing interference.

In the Differentiate or die publication [19] the authors state that human mind does not like coping with complexity and chaos and so the best way is to simplify. Not only for precision rifles, but also for any new product, finding or creating a new market space is the best way to proceed. Precision rifles are not exclusive only for specialists from the armed forces. Other big potential target groups are sport shooters and hunters. Most of the end users are either professionals or educated and experienced amateurs. Precision long-range shooting is not just about guns or barrels, but also about every little detail and often about the very short time of the actual shot. All long-term preparation and training will take place in a single and unique fraction of a second, and especially for professionals, any mistake can have far-reaching consequences. So it is no wonder that users of precision rifles are fussy and conservative. 
The required accuracy of weapons is most often given in minutes of angle, also referred to as $\mathrm{MOA}$, and for precision rifles it is a common requirement to have a $1 / 2 \mathrm{MOA}$. Thus, at $500 \mathrm{~m}$, a $145.5 \mathrm{~mm}$ tolerance is possible for this gun. For most professionals, such accuracy is inadequate, and they achieve much better results with their own rifles. And that is why these shooters do not like to switch to different guns then those that have been tested in a long-term. But what they do like, is trying new products, but before these products gain their trust, they must undergo a long-term testing under all foreseeable conditions of use.

Finding a unique communication direction that convinces such a user is not a simple challenge. As mentioned above, the final requirements and needs of individual customer groups differ. Not even a breakthrough in product performance can be the ultimate decision-making impulse for a purchase. Yet, from the marketing communication point of view, composite materials bring several changes to the production of the precision rifles barrels. Weight reduction of $51-56 \%$ is very interesting for users who must often hike long trails in a difficult terrain and every gram saves their energy or presents an opportunity to take along more ammunition. On the contrary, for snipers or sport shooters who have the opportunity to come to the shooting site, it is only a nice improvement, nothing essential. The reliability of the cold shot and the ability to keep the shots are also very important. Yet every user places a different emphasis on them. Therefore, if we are interested in reaching such sophisticated users, we need to offer them a clear and unique advantage while maintaining all the other benefits of the new materials or designs.

In the case of precision rifles, said sales argument may be individual preparation mainly for specific use. The article has demonstrated that the development of a new special is a complex, long and expensive process. The results of the initial tests of mathematical modelling and experimental firing [17] give hope that instead of a long-term development, the manufacturer will be able to verify and model the demanded properties according to the customer's requirements and then produce a product according to the prepared and mathematically proven technology of wrapping the composite to the steel core. Therefore, the phase of long development and testing will be eliminated, which will significantly reduce the time to deliver the product with specific features meeting all the needs and requirements of the users.

The market of precision rifles could not use this sort of launching before because there were no prerequisites for it without experimentally verified calculations for the production of products with predefined properties. This approach is not generally known; designing in construction shall serve as an example.

\section{CONCLUSION}

The aim of the article was to find out the main factors influencing the future marketability of precision rifles using new composite materials combined with steel to produce precision rifle barrels. The paper presents main risks, describes the procedure of the research team, whose work was contributed by the authors of this paper, and the main outcomes that should significantly help the given assignment. In the approach above, there is an innovative presentation of individual product characteristics that cannot be precisely measured or otherwise grasped. Users are in the position of a designer of the required qualities that the manufacturer might not have taken into account during standard development. The authors of the article assume that this communication strategy will be successful in conservative industries and customers and in the fields with long-term innovation cycles. New materials or design solutions can be put through like this in a way that provides a longer-term competitive advantage, as imitating or levelling will require long and complex research by followers.

\section{ACKNOWLEDGEMENTS}

The article was supported by a specific university research by Ministry of Education, Youth and Sports of the Czech Republic No. SP2018/22 Risk Management Study of Industrial Enterprises in the Czech Republic. 


\section{REFERENCES}

[1] LAMPA, Martin, JANOVSKÁ, Kamila and BESTA, Petr. Innovative access to solution two-dimensional cutting problem in metallurgical operations. In METAL 2013 - 22nd International Conference on Metallurgy and Materials. Ostrava: TANGER, 2013, pp. 1971-1976.

[2] BESTA, Petr, SAMOLEJOVÁ, Andrea, LENORT, Radim and ZAPLETAL, František. Innovative application of mathematical methods in evaluation of ore raw materials for production of iron. METALURGIJA. 2014. vol. 53, no. 1, pp. 93-96.

[3] PARK, Hyunbum. Investigation on low velocity impact behavior of sandwich composite and monolithic laminate plates using FEM analysis. Composite Structures. 2019. vol. 220, no. July 2019, pp. 842-846.

[4] TRUONG, Viet Hoai, KWAK, Byeong Su, ROY, René J. and KWEON, Jin Hwe. Cohesive zone method for failure analysis of scarf patch-repaired composite laminates under bending load. Composite Structures. 2019. vol. 222, no. August 2019, article number 110895.

[5] AKÇA, Cem and ERARSLAN, Yaman. T zone of SIC particulate reinforced AZ91D magnesium alloys under ballistic impact on a specially designed gravitational ballistic test apparatus. In METAL 2013 - 22nd International Conference on Metallurgy and Materials. Ostrava: TANGER, 2013, pp. 1418-1422.

[6] CHEN, Yu Liang, WANG, Chih Feng, LIN, Ying Chih, BOR, Hui Yun Y. and NI, Cuo Yo. Ballistic resistance capability analysis of aluminum alloy with fiber composites. Chung Cheng Ling Hsueh Pao/Journal of Chung Cheng Institute of Technology. 2014. vol. 43, no. 1, pp. 149-158.

[7] JIA, Xiaolong, HUAN, Xianhua, QI, Pengfei, SUI, Gang, LI, Gang, YU, Yunhua and YANG, Xiaoping. Performance improvement in carbon fiber reinforced polymer-based composites. Kexue Tongbao/Chinese Science Bulletin. 2018. vol. 63, no. 34, pp. 3555-3569.

[8] SIMMS, Janet E., SIGMAN, John B., BARROWES, Benjamin E., BENNETT, Hollis H., YULE, Donald E., O'NEILL, Kevin A. and SHUBITIDZE, Fridon I. Initial Development of a High-frequency EMI Sensor for Detection of Subsurface Intermediate Electrically Conductive (IEC) Targets. Journal of Environmental and Engineering Geophysics. 2017. vol. 22, no. 2, pp. 111-120.

[9] ROJEK, Maciej, SZYMICZEK, Małgorzata, STABIK, Józef, MĘŻYK, Arkadiusz, JAMROZIAK, Krzysztof, KRZYSTAŁA, Edyta and KUROWSKI, Janusz. Composite materials with the polymeric matrix applied to ballistic shields. Archives of Materials Science and Engineering. 2013. vol. 63, no. 1, pp. 26-35.

[10] CHRISTENSEN, Roland. Patent číslo WO 97/22843. Název patentu Improved Composite/Metallic Gun Barrel, datum patentování 26.06.1997, Aplikační číslo patentu PCT/US96/20304, datum podání patentu 04.06.2003, Mezinárodní aplikační číslo F41A 21/20.

[11] YAN, Lutao, ZHANG, Qinjian, WANG, Jinhai and YU, Jingzhou. Effect of ultrasonic vibration on tribological behavior of carbon-carbon composite. Tribology International. 2019. vol. 136, no. August 2019, pp. 469-474.

[12] VILAMOVÁ, Šárka, BESTA, Petr, KOZEL, Roman, PIECHA, Marian, VANĚK, Michal, SAMOLEJOVÁ, Andrea, JANOVSKÁ, Kamila and ČECH, Martin. Increasing the Efficiency of Production of Iron by Means of Reduction of Harmful Elements. METALURGIJA. 2015. vol. 54, no. 4, pp. 649-652.

[13] VILAMOVÁ, Šárka, BESTA, Petr, KOZEL, Roman, JANOVSKÁ, Kamila, PIECHA, Marian, LEVIT, Adam, STRAKA, Martin and ŠANDA, Martin. Quality Quantification Model of Basic Raw Materials. METALURGIJA. 2016. vol. 55, no. 3, pp. 375-378.

[14] KUSNEROVA, Milena, REPKA, Michal, HARNICAROVA, Marta, VALICEK, Jan, DANEL, Roman, KMEC, Jan and PALKOVA, Zuzana. A new method of semi-automated measurement of shear friction coefficient. TEM Journal. 2018. vol. 7, no. 4, pp. 924-932.

[15] PESZYNSKA-BIALCZYK, Katarzyna, KRKOSKA, Milan, PAWLICZEK, Adam, FILIP, Peter and ANDERSON, Ken. Study of "adsorption/desorption" phenomena on friction debris of aircraft brakes. Ceramic Engineering and Science Proceedings. 2005. vol. 26, no. 8, pp. 157-166.

[16] MOCHAR, Dominik, GABRIEL, Dušan, TRNKA, Jan, CHLADA, VALEŠ, František, MASÁK, Jan. Experimentální a MKP analýza kompozitni hybridni hlavně. Výzkumná zpráva k projektu č. TH01010772.

[17] MOCHAR, Dominik, TRNKA, Jan, CHLADA, Milan, VALEŠ, František, GABRIEL, Dušan, ČERV, Jan and VTíPIL, Jaroslav. Experimental and finite element analysis of composite gun barrels. In 24th International Conference Engineering mechanics 2018. Prague: Institute of Theoretical and Applied Mechanics of the Czech Academy of Sciences, 2018, pp. 557-560.

[18] VOJTA, Vít. Umění války. Využití válečných strategií v byznysu. Brno: BizBooks, 2014. s. 208.

[19] TROUT, Jack a RIKVIN, Steve. Odliš se nebo zemři. Jak si zajistit úspěch na trhu jedinečností své nabídky. Praha: Grada Publishing, 2006. s. 200. 